\title{
A Study on Contamination of Fresh Water Aquifers with Fluoride Through Domestic Sewage in Puttur Town - D.K.
}

\author{
Suresh Babu B.T. ${ }^{1}$ and Amar S. Byakodi ${ }^{2}$
}

\begin{abstract}
Fluoride intake with drinking water is severe problem in several places in the country. Moderate amount of fluoride leads to dental fluorosis, but long term ingestion of large amounts can lead to potentially severe skeletal problems. Keeping in view this factor, a study was planned to know the status of fluoride concentration of fresh water aquifers contaminated through domestic sewage. Among 98 existing ground water sources, 48 fresh water aquifer are indentified which are adjacent to open raw sewage disposal drains, health centres and major hospitals. Physico-chemcial parameters are analyzed for the collected sample for three months in three cycles at an interval of 30 days. The fluoride content varied from 0.04 to $0.14 \mathrm{mg} / 1$ during the study period. The value of $\mathrm{pH}$ varied from 4.80 to 8.29 and $58.33 \%$ of the sources shows a $\mathrm{pH}$ value less than 6.50 . Similarly, $6.25 \%$ of the sources shows a sulphate concentration more than the prescribed limit of $200 \mathrm{mg} / \mathrm{l}$. Results of the study indicate ground water aquifers are not contaminated with fluoride and are suitable for drinking purpose.

Key words: Fluoride, Freshwater aquifers, Domestic sewage.
\end{abstract}

\section{INTRODUCTION}

Most of the demand for water is fulfilled by rainfall which gets deposited in surface and subsurface sources. The quantity of water available is rapidly deteriorating because of urbanization, industrialization, agriculture, increase in population and fast growing technologies. As a result of human activities, the fresh water resources are becoming less suitable for drinking and domestic use. Groundwater is one of the major sources of freshwater and contains dissolved ions but beyond a permissible limit is harmful and not suitable for domestic use. Fluoride are mainly found in groundwater and derived by solvent action of water on rocks and soil in the earth crust. Higher levels of fluoride concentration in groundwater in certain areas which become endemic for fluorisis. It is very much necessary to consider remedial measures to control fluorosis, if fluoride levels in the potable water are beyond the permissible limit. Fluoride enters the aquatic system in dissolved form through domestic and industrial discharges. As per World Health Organization (WHO) and Bureau of Indian Standards (BIS), the fluoride content in drinking water should be in the range of 1.0 to 1.50 $\mathrm{mg} / \mathrm{l}$. There are two main sources of fluoride available: one is natural and other is artificial sources. The main source of fluoride in ground water is fluoride bearing rocks such as fluorospar, fluorite, cryolite and fluorapatite. Also the content in ground water is a function of many functions such as

\footnotetext{
${ }^{1}$ Dept. of Civil Engineering, Angadi Institute of Technology and Management, Belagavi, Karnataka, India

${ }^{2}$ Dept. of Civil Engineering, Angadi Institute of Technology and Management, Belagavi, Karnataka, India.
} 
availability and solubility of fluoride minerals, velocity of flowing water, $\mathrm{pH}$, temperature and concentration of calcium and bicarbonate ions in water. These fluoride minerals are soluble in water and present in sedimentary rocks and in underground strata.

Long term consumption of water containing $1 \mathrm{mg} / 1$ leads to dental fluorisis, white and yellow teeth patches will form on teeth and gradually turns to brown and formation of horizontal streaks. Skeletal fluorisis has been observed in persons where the consumption of water containing 3.0 to $6.0 \mathrm{mg} / 1$ which affects both young and older individuals. Fluoride can also damage the foetus if the mother consumes water and food high concentration of fluoride during pregnancy. It causes severe pain and stiffness in the back bone, hip joints and other joints of skeletal system in our body. X-rays of bones shows increase thickening and density of bones and also cause narrowing of vertebral column producing pressure on nerves leading to paralysis. Fluorosis is one of the incurable disease in the world and the only way of prevention is to maintain the amount of fluoride intake through various sources.

\section{STUDY AREA}

Dakshin Kannada district is situated in coastal region of south-western part of Karnataka and has a population of eighteen lakhs. The district has five talukas: Mangalore, Puttur, Sullia, Beltangadi and Bantwala. Among all, Puttur is one of the biggest taluk and situated in central part of the district.

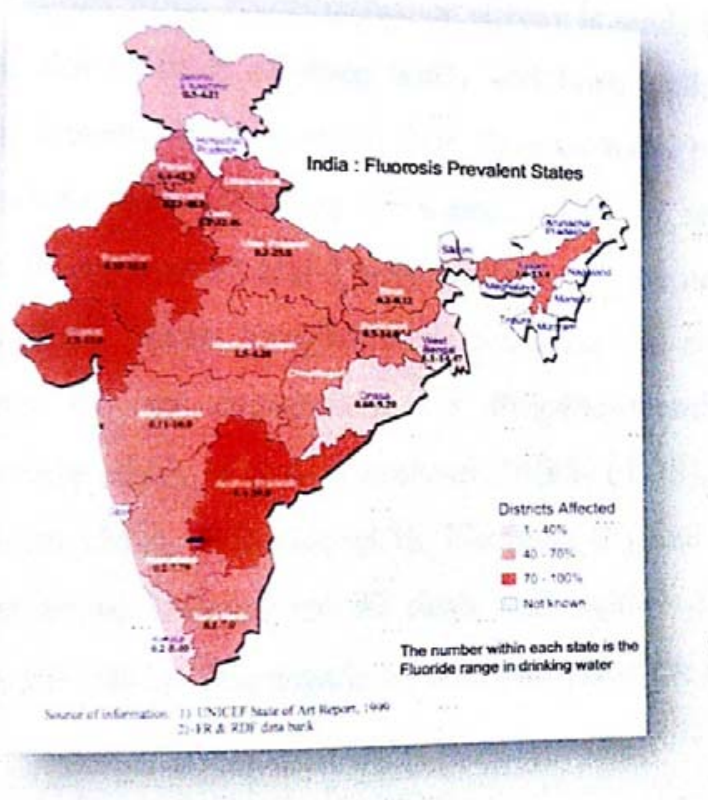

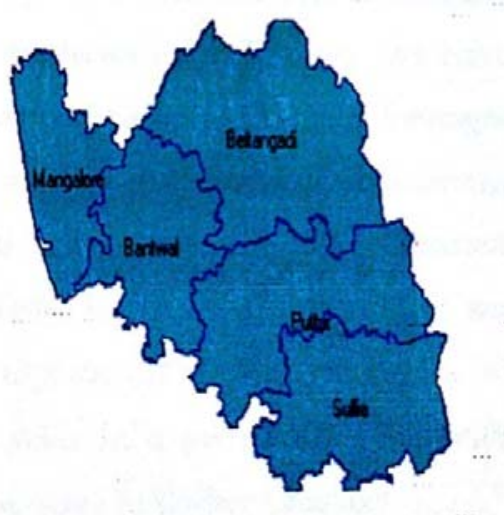

DAKSHINA KANNADA

Figure 1: Locations Puttur town.

Puttur is taluk head quarters with a population of $60,000 \pm 10,000$ (floating population) and has a number of educational institution, industries and agricultural activities. It is $52 \mathrm{~km}$ away from Mangalore towards south east. Puttur town is surrounded by Netravathi and Kumaradhara rivers, flowing towards south west and joining Arabian sea at Managlore. Town municipal council extends over an area about $10 \mathrm{sq} . \mathrm{km}$. The entire area is divided into single zone for effective management of solid waste covering 27 wards in the town. 
Most of the people living in Puttur depend in muncipal water supply and fresh water open wells for their daily uses. It is observed that there is no underground drainage system for the disposal of sewage. Only open drainage systems are provided covering $60 \%$ to $70 \%$ of the total city area, to dispose sullage water generated in the town. It is even very difficult for the municipality to provide underground drainage system since, Puttur town is underlain by rocky strata with sedimentary rock system. Considering all these factors, it is observed that most of the sewage generated is absorbed by lateritic soil strata and hence there might be a chance of groundwater pollution.

In the present study, reconnaissance survey is made to find the number of open wells and bore wells along with status of drainage system. There are 90 open wells and 8 bore wells existing in entire city and for the study, only 46 open wells and 2 bore wells are selected which are located in the vicinity of open drains and hospitals. Water samples are collected at an interval of 30 days and same is carried for three consecutive months.

\section{MATERIALS AND METHODOLOGY}

Most of the people in Puttur town are mainly dependent on open wells and municipal water supply system. Through reconnaissance survey existing status of the drainage system and water sources are determined. The radial distance of town is about $4 \mathrm{~km}$ and selection of open wells are made based on its location.

High concentration of fluoride is present in cosmetic items i.e. toothpaste and mouth rinsing solutions which are more attractive in present scenario. More than 50 varieties of toothpaste and dental concern items are available in the market. It is observed that if one gram of toothpaste is used by a person, then entire consumption of Puttur town is around $60 \mathrm{~kg}$ considering its population. Most of these products contain fluoride in concentration more than $1000 \mathrm{mg} / \mathrm{l}$. Since there is no proper drainage system in the town and having rich latratic strata, most of the sewage along with sullage enters the groundwater and the same may enter into the open wells which is major source of water.

Samples are collected from selected open wells and bore wells, preserved as per the standard methods. The samples are analyzed for various physico-chemical properties viz. $\mathrm{pH}$, conductivity, total dissolved solids, total hardness, chloride, sulphate and fluoride.

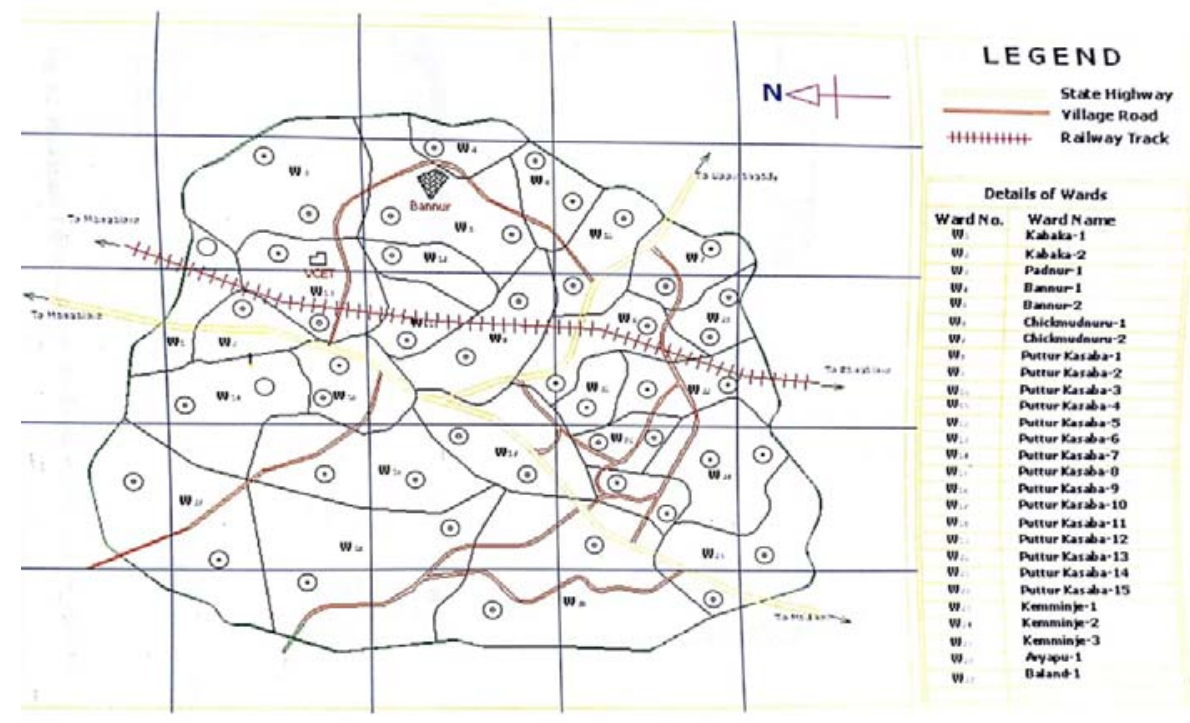

Figure 2: Locations of various open wells in Puttur town. 


\section{RESULTS AND DISCUSSION}

Groundwater has become major source of water in some of the areas for domestic water supply, industry and agricultural sectors. Generally most of the groundwater sources have higher concentration of fluoride than surface water. As water percolates through various layers of rock strata containing fluoride, concentration of the same increases and it depends on geological formations, temperature, $\mathrm{pH}$, solubility of fluoride bearing minerals. The concentration of fluoride in groundwater can range from $1.0 \mathrm{mg} / 1$ to $35.0 \mathrm{mg} / \mathrm{l}$.

Present study mainly focuses on effects of sewage infiltration into groundwater, quality assessment of groundwater and also the effect of fluoride on groundwater aquifer in Puttur town. The study is conducted over a period of three moths and samples are collected from 46 open wells and 2 bore wells at an interval of thirty days. Details of the physico-chemical parameters analyzed are shown in table 1.

Table 1: Range of physico-chemical parameters analyzed in three cycles in Puttur town.

\begin{tabular}{|c|c|c|c|c|c|c|c|c|c|c|c|c|c|c|c|c|c|}
\hline \multirow{3}{*}{$\begin{array}{l}\text { Sl. } \\
\text { No } \\
\text {. }\end{array}$} & \multirow{3}{*}{$\begin{array}{l}\text { Cycl } \\
\text { e } \\
\text { No. }\end{array}$} & \multicolumn{16}{|c|}{ Parameters Analyzed } \\
\hline & & \multicolumn{4}{|c|}{ Physical Parameters } & \multicolumn{12}{|c|}{ Chemical Parameters } \\
\hline & & \multicolumn{2}{|l|}{$\mathrm{pH}$} & \multicolumn{2}{|c|}{$\operatorname{TDS}_{(\mathrm{mg} / \mathrm{l})}$} & \multicolumn{2}{|c|}{$\begin{array}{l}\text { Total } \\
\text { Hardness } \\
(\mathrm{mg} / \mathrm{l}\end{array}$} & \multicolumn{2}{|c|}{$\begin{array}{l}\text { Calcium } \\
\text { as } \mathrm{Ca}_{(\mathrm{mg} / \mathrm{l})}\end{array}$} & \multicolumn{2}{|c|}{$\begin{array}{l}\text { Magnesium } \\
\text { as } \mathrm{Mg}_{(\mathrm{mg} / \mathrm{l})}\end{array}$} & \multicolumn{2}{|c|}{$\begin{array}{l}\text { Chloride as } \\
\mathrm{Cl}_{(\mathrm{mg} / \mathrm{l})}\end{array}$} & \multicolumn{2}{|c|}{$\begin{array}{l}\text { Sulphate } \\
\text { as } \quad \mathrm{SO}_{4}\end{array}$} & \multicolumn{2}{|c|}{$\begin{array}{l}\text { Fluoride } \\
(\mathrm{mg} / \mathrm{l})\end{array}$} \\
\hline \multirow{2}{*}{\multicolumn{2}{|c|}{$\begin{array}{l}\text { Water } \\
\text { Quality } \\
\text { Standards } \\
\text { BIS: } \\
10500- \\
2003\end{array}$}} & \multicolumn{2}{|c|}{6.5 to 8.5} & \multicolumn{2}{|c|}{$500 \& 2000$} & \multicolumn{2}{|c|}{$300 \& 600$} & \multicolumn{2}{|c|}{$75 \& 200$} & \multicolumn{2}{|c|}{$30 \& 100$} & \multicolumn{2}{|c|}{$250 \& 1000$} & \multicolumn{2}{|c|}{$\begin{array}{l}200 \\
400\end{array} \quad \&$} & \multicolumn{2}{|c|}{$1.0 \& 1.5$} \\
\hline & & $\begin{array}{l}\mathrm{Mi} \\
\mathrm{n} .\end{array}$ & $\begin{array}{l}\text { Ma } \\
\mathrm{x} .\end{array}$ & $\begin{array}{l}\mathrm{Mi} \\
\mathrm{n} .\end{array}$ & Max. & Min. & $\begin{array}{l}\text { Ma } \\
\text { x. }\end{array}$ & Min. & $\begin{array}{l}\mathrm{M} \\
\mathrm{a} \\
\mathrm{x}\end{array}$ & Min. & $\begin{array}{l}\text { Ma } \\
\text { x. }\end{array}$ & $\begin{array}{l}\text { Min } \\
\text {. }\end{array}$ & $\operatorname{Max}$ & $\begin{array}{l}\mathrm{Mi} \\
\mathrm{n} .\end{array}$ & $\begin{array}{l}\text { M } \\
\text { ax. }\end{array}$ & Min & $\begin{array}{l}\text { Ma } \\
\mathrm{x} .\end{array}$ \\
\hline 1 & $\mathrm{C} 1$ & \multicolumn{2}{|c|}{4.8 to 7.5} & \multicolumn{2}{|c|}{51 to 452} & \multicolumn{2}{|c|}{16 to 240} & \multicolumn{2}{|c|}{2 to 56} & \multicolumn{2}{|c|}{0 to 33} & \multicolumn{2}{|c|}{6 to 92} & \multicolumn{2}{|c|}{0 to 107} & \multicolumn{2}{|c|}{0.04 to 0.14} \\
\hline 2 & $\mathrm{C} 2$ & \multicolumn{2}{|c|}{5.4 to 8.3} & \multicolumn{2}{|c|}{52 to 426} & \multicolumn{2}{|c|}{16 to 152} & \multicolumn{2}{|c|}{3 to 42} & \multicolumn{2}{|c|}{0 to 33} & \multicolumn{2}{|c|}{2 to 100} & $19 \mathrm{tc}$ & 319 & 0.04 & 0.13 \\
\hline 3 & $\mathrm{C} 3$ & $4.9 t$ & 7.6 & $61 \mathrm{t}$ & 415 & 17 to & & 3 to 4 & & 1 to 2 & & 2 to & & $23 \mathrm{t}$ & 348 & 0.04 & 0.12 \\
\hline
\end{tabular}

\section{CONCLUSION}

Detail study has been carried out to know the contamination of freshwater aquifers with fluoride through domestic sewage. The city contains 90 open wells and 8 bore wells, out of which 46 open wells and 2 bore wells are selected for the study in Puttur town. It is observed that most of the area in the town is having lateritic zone and it is having high porosity and efficient in the process of infiltration of water and wastewater. In this study laboratory expectorants were carried out on various ground water samples collected from all 27 wards. Physico-chemical analysis is made based on the samples collected and following conclusions are made based on the study conducted:

- It is evident from this investigation, fluoride content in $79 \%$ of water samples are less than 0.1 $\mathrm{mg} / \mathrm{l}$.

- It is observed that fluoride contamination through sewage interference into the fresh water aquifers is almost nil and safe for drinking purpose.

- Less concentration of fluoride in drinking water causes dental carries, formation of cavities in teeth and softening of bones, hence fluoridation is necessary before consuming these water.

- Even though huge quantity of fluoridated toothpaste and mouth rises are consumed in the town every day(more than, $60 \mathrm{~kg} /$ day) there is no much effect on public health. 
- Lateritic zone is acting as very good adsorbent in the removal of fluoride entering from sewage, even though there is no proper drainage system in the town.

\section{SCOPE FOR FUTURE STUDY}

Based on the study made on the present work, some of the suggestions are made for future enhancement,

- It is necessary to carry out the efficiency of laterite in the removal of fluoride as an adsorbent media.

- Amount of fluoride required in the process of fluoridation is to be studied.

- It is necessary to carry out a detailed survey in puttur town to know the dental carries problems if any.

- Interference of organic and inorganic substances entering into the freshwater aquifer is to be studied.

- Bacteriological analysis of water from freshwater aquifers is to be made.

\section{REFERENCES}

1. Sunita V., Muralidhara Reddy B, Ramakrishna Reddy M., "Variation of Fluoride and correlation with alkalinity in groundwater of shallow and deep aquifers", International Journal of Applied Science and engineering Research, Vol. 1, Issue 4, pp 569-575, 2012.

2. Ramesam V., Rajgopalan K., "Fluoride ingestion into the natural water of Hard rock areas, Peninsular India", Journal Geological Society of India, Vol. 26, pp 125-132.

3. Sawyer and Mc. Carty, "Chemistry for Environmental Engineering", American Public Health Association, New York, 5th Edition, pp 401-624, 2006.

4. APWHA, "Standard methods for the Examination of Water and Wastewater", American Public Health Association, New York, 22nd edition, 2012.

5. BIS: 10500-2003, Water Quality Standards, pp 5-8. 